\title{
PENGEMBANGAN MEDIA PEMBELAJARAN PERMAINAN TRUTH AND DARE PADA MATA PELAJARAN AKUNTANSI DASAR KELAS X AKUNTANSI DI SMK NEGERI 1 SAMBENG LAMONGAN
}

\author{
${ }^{1}$ Andi Permana, ${ }^{2}$ Rochmawati \\ Program Studi Pendidikan Akuntansi, Fakultas Ekonomi, Universitas Negeri Surabaya \\ Alamat e-mail : andipermana16080304014@mhs.unesa.ac.id
}

\begin{abstract}
ABSTRAK
Penelitian ini bertujuan untuk mengembangkan media pembelajaran permainan truth and dare dengan subyek penelitian adalah siswa kelas $X$ kompetensi keahlian akuntansi pada mata pelajaran akuntansi dasar sub pokok bahasan siklus akuntansi dan penjurnalan. Pengembangan penelitian ini mengadopsi model 4D dari Thiagarajan, yaitu pendefinisian, perancangan, pengembangan, dan penyebaran. Hasil validasi dan telaah penelitian ini menunjukkan kelayakan media sebesar 96\% dan kelayakan materi memperoleh rata-rata sebesar 91\% dengan kriteria sangat layak.

Kata kunci : media pembelajaran, permainan truth and dare, akuntansi dasar
\end{abstract}

\section{ABSTRACT}

The research is aimed to develop media truth and dare game as for the subjects of the study were the students of $X$ Grade from accounting competency departement on topic of basic accounting of the accounting and journalizing cycle. This study adopted Thiagarajan 4D model consist of define, design, develop, and dissamenate. The result of the validation and study of this study indicate the feasibility of the media $96 \%$ and the feasibility of the material to get an average of $91 \%$ with very decent criteria.

Keywords: Media learning, Truth and dare game, Basic accounting

\section{PENDAHULUAN}

Pengembangan pembelajaran pada kurikulum 2013 bertujuan agar pendidikan di Indonesia mampu menyiapkan manusia yang produktif, kreatif, inovatif dan afektif. Dalam kurikulum 2013 terdapat 4 aspek penilaian yaitu aspek pengetahuan, sikap, keterampilan, dan perilaku. Dalam proses pelaksanaan kurikulum 2013 memerlukan beberapa faktor pendukung salah satunya yaitu media pembelajaran. Peran media pembelajaran sangat penting karena dengan adanya media dapat meningkatkan minat serta motivasi siswa dalam mengikuti proses pembelajaran.

Sekolah SMK Negeri 1 Sambeng merupakan sekolah adiwiyata yang terdapat delapan kompetensi keahlian salah satunya adalah akuntansi. Pada kompetensi keahlian akuntansi terdapat tiga tingkatan yaitu kelas $\mathrm{X}, \mathrm{XI}$, dan XII dimana masing-masing tingkatan terdapat satu kelas.

Pada program kompetensi keahlian akuntansi kelas $\mathrm{X}$ terdapat mata pelajaran akuntansi dasar. Pada materi ini memperlajari tentang teori-teori dan skilus di dalam akuntansi, dengan banyaknya materi yang harus dikuasai oleh siswa, seorang pendidik harus memberikan stimulus yang sesuai sasaran, salah satunya menggunakan media pembelajaran yang tepat sehingga di dalam setiap proses pembelajaran dapat meningkatkan minat serta motivasi siswa dalam belajar.

Proses pembelajaran pada mata pelajaran akuntansi dasar di SMK Negeri 1 Sambeng menggunakan media pembelajaran papan tulis, LCD serta power point dengan metode ceramah. Dengan adanya media tersebut jika dilakukan terus menerus dapat mengakibatkan siswa mudah merasa bosan dan kurang aktif didalam pembelajaran. Namun permasalahan ini dapat diperbaiki dengan cara menggunakan media pembelajaran permainan yang tepat sehingga dengan adanya media pembelajaran permainan tersebut dapat menambah kemampuan komunikatif dan mototrik siswa, serta dengan adanya media pembelajaran 
permainan yang memiliki kelebihan menarik dan meneyenangkan dapat meningkatkan minat dan motivasi siswa didalam pembelajaran mata pelajaran akuntansi dasar.

Materi dari pada peserta didik harus membaca, menghafal dan mendengarkan pendidik terus menerus sehingga dapat membuat siswa mudah merasa bosan. Penelitian ini dilakukan pada siswa kelas $X$ akuntansi di SMK Negeri 1 Sambeng karena siswa kelas $X$ cenderung memiliki karakteristik yang beragam, sehingga dengan adanya media pembelajaran permainan ini diharapkan dapat meningkatkan minat dan semangat siswa tersebut. Dalam penelitian ini menggunakan materi akuntansi dasar karena dimateri ini terdapat banyak teori serta keterampilan yang harus tersampaikan dan sesuai dengan media permainan yang akan dikembangkan. Pada materi akuntansi dasar kelas $X$ akuntansi dalam media permainan truth and dare ini sangat sesuai, dimana materi ini meliputi pengertian akuntansi, akun-akun dalam akuntansi, tahapan siklus akuntansi, transaksi dalam perusahaan jasa, dagang dan manufaktur serta pembukuan jurnal. Dengan banyaknya materi yang ada pada mata pelajaran akuntansi dasar tersebut diharapkan siswa dapat memahami dan mengingat materi-materi tersebut dengan cepat. Peneliti memilih pengembangan media pembelajaran permainan truth and dare karena memiliki kelebihan yang sangat cocok jika diterapkan pada proses pembelajaran siswa kelas $X$ akuntansi di SMK Negeri 1 Sambeng karena siswa kelas $X$ di SMK tersebut cenderung senang diajak belajar sambil bermain.

Media pembelajaran permainan mempunyai kelebihan yaitu permainan adalah suatu yang menyenangkan untuk dilakukan karena menghibur dan menarik (Sadiman, 2014). Dengan adanya media pembelajaran permainan akan menimbulkan motivasi serta minat siswa dalam proses pembelajaran. Media pembelajaran merupakan alat bantu atau pelengkap yang digunakan pendidik atau guru untuk berkomunikasi dengan siswa atau peserta didik.

Berdasarkan hasil analisis yang perna dilakukan oleh Nur Indah Sari (2015) dapat disimpulkan bahwa media pembelajaran permainan kartu dapat meningkatkan hasil belajar siswa berdasarkan penilaian ahli materi sebesar $91,4 \%$, penilaian ahli media sebesar $92,23 \%$ dan dinyatakan layak untuk digunakan dengan hasil respon siswa sebesar 97,9\%. Maka dengan berdasarkan penelitian yang relevan terdahulu yang perna dilakukan, hasil pengamatan peneliti serta wawancara kepada guru mata pelajaran tersebut bahwa media pembelajaran permainan truth and dare belum perna dilakukan atau diterapkan pada mata pelajaran akuntansi dasar kelas X akuntansi di SMK Negeri 1 Sambeng, serta fakta sekolah siswa lebih suka bermain dengan teman sebayanya. maka peneliti melakukan penelitian dengan judul "Pengembangan Media Pembelajaran Permainan Truth and Dare Pada Mata Pelajaran Akuntansi Dasar Kleas X Akuntansi Di SMK Negeri 1 Sambeng".

Rumusan masalah dalam penlitian ini (1) Bagaimana proses pengembangan media pembelajaran permainan Truth and Dare di SMK Negeri 1 Sambeng? (2) Bagaimana kelayakan media permainan Truth and Dare pada kelas X Akuntansi SMK Negeri 1 Sambeng?

Sedangkan tujuan dari adanya penelitian ini adalah (1) Mengembangkan proses media pembelajaran permainan Truth and Dare di SMK Negeri 1 Sambeng. (2) Menganalisis kelayakan media permainan Truth and Dare pada kelas X Akuntansi SMK Negeri 1 Sambeng.

\section{METODE PENELITIAN}

Penelitian ini merupakan peneLitian pengembangan media pembelajaran yang menggunakan media permainan Truth and Dare menggunakan model pengembangan yang mengadaptasi Thiagarajan yaitu 4-D meliputi Define (Pendefinisian), Design (Perancangan), Develope (Pengembangan), Deseminate (Penyebaran). Pada penelitian ini memiliki keterbatasan yaitu hanya sampai di tahap ketiga saja yaitu tahap pengembang (Develop), hal ini dikarenakan uji coba produk tidak dapat dilaksanakan secara langsung dikarenakan adanya dampak virus convid19.

Instrumen penelitian yang digunakan adalah lembar telaah dan validasi oleh para ahli yang termasuk data kualitatif. Lembar telaah dan surat validasi digunakan untuk tiga ahli validator yaitu dua orang ahli materi (guru SMKN 1 Sambeng dan dosen ahli mata kuliah akuntansi dasar), dan satu orang ahli media. Kemudian hasil validasi para ahli akan dianalisis kelola peneliti dengan skala likert seperti di bawah ini. 
Tabel 1. Kriteria Penskoran Skala Likert

\begin{tabular}{cc}
\hline Kriteria & Skor \\
\hline Sangat layak & 5 \\
Layak & 4 \\
Cukup layak & 3 \\
Tidak layak & 2 \\
Sangat tidak layak & 1 \\
\hline Sumber : (Riduwan, 2016)
\end{tabular}

Setelah data penilaian hasil validasi dari para ahli kemudian akan dijabarkan dan dikelola dalam skala likert, selanjutnya dianalisis menggunakan rumus sebagai berikut :

$$
\text { Prosentase }=\frac{\text { Jumlah Skor } \text { Total" }}{\text { Jumlah Skor Maksimal }} \times 100 \%
$$

Sumber : (Riduwan, 2016)

Hasil perhitungan diatas, berupa prosentase yang dijabarkan dalam kriteria interpretasi media evaluasi dengan skala likert berikut ini :

Tabel 2. Interpretasi Penskoran Skala Likert

\begin{tabular}{cc}
\hline Kriteria & Kriteria \\
\hline $81-100$ & Sangat layak \\
$61-80$ & Layak \\
$41-60$ & Cukup layak \\
$21-40$ & Tidak layak \\
$0-20$ & Sangat tidak layak \\
\hline
\end{tabular}

Sumber : (Riduwan, 2016)

Hasil kriteria interpretasi tersebut menggambarkan kelayakan media pembelajaran permainan truth and dare.

Sedangkan angket peserta didik berupa data kuantitatif, pada data tersebut terdapat prosentase yang mengacu pada skala Gutman yang dimana skor 1 untuk jawaban "ya" dan skor 0 untuk jawaban "tidak". Berdasarkan hasil analisis di atas, dapat diambil kesimpulan media pembelajaran permainan truth and dare dikatakan layak jika prosentase yang dihasilkan mencapai $\geq 61 \%$.

\section{HASIL DAN PEMBAHASAN}

Pada proses pengembangan media pembelajaran permainan truth and dare terdapat tahap define yang merupakan analisis ujung depan yang dapat dilakukan mulai dari analisis kurikulum, yang bertujuan untuk menetapkan kompetensi dan bahan ajar yang dikembangkan. Analisis kurikulum diawali dengan pengetahuan, keterampilan, dan sikap yang dimiliki peserta didik untuk mencapai tujuan yang tercantum didalam kurikulum. Peneliti juga mengamati bahwa permainan truth and dare ini sudah tidak asing lagi pada semua siswa. Beberapa penelitian terdahulu menyatakan bahwa media pembelajaran truth and dare ini layak digunakan, berdasarkan analisis yang dilakukan oleh Bics Al Hibra (2012) dapat disimpulkan bahwa media pembelajaran truth and dare mendapatkan hasil validasi rata-rata persentase sebesar 93,67\% oleh ahli media, validasi bahasa dan kontruksi sebesar $87,3 \%$ dikatakan efektif terbukti dari hasil belajar siswa yang ditunjukkan dengan adanya peningkatan hasil belajar. Berdasarkan jurnal penelitian internasional yang dilakukan oleh Hasan Rastegarpour dan Poopak Marashi (2011) penelitian menunjukkan bawah skor ratarata kelompok eksperimen mengalami peningkatan hasil pembelajaran secara signifikan sehingga dapat dikatakan bermain game didukung dengan pembelajaran aktif dan konsentrasi dapat meningkatkan hasil belajar dan meningkatkan interaksi dengan teman sebaya. Peneliti menganalisis membuat soal-soal pengayaan mata pelajaran akuntansi dasar 
dengan 4 pokok Bab pembahasan yaitu: (1) Bab 1 siklus didalam akuntansi (2) Bab 2 persamaan dasar akuntansi. (3) Bab 3 memahami transaksi bisnis perusahaan jasa, dagang dan manufaktur. Soal dari tiga bahasan materi tersebut dirancang pembuatan soal dan kartu soal dirancang 10 soal kartu truth dan 15 soal kartu dare. Pada media ini guru sebagai pemimpin dalam permainan dimana tugas guru menjelaskan kembali atas jawaban yang telah dijawab oleh siswa merujuk pada kunci jawaban yang ada di buku panduan.

Jika media pembelajaran truth and dare yang dirancang peneliti tersebut telah siap dikembangkan pada pembelajaran, maka selanjutnya media pembelajaran ditelaah dan divalidasi oleh ahli materi dan ahli media. Dari hasil telaah tersebut akan menghasilkan saran dan komentar yang akan dijadikan acuan bagi peneliti untuk merevisi media yang telah memerlukan perbaikan. Jika proses telaah selesai selanjutnya media pembelajaran permaianan truth and dare akan divalidasi. Validasi merupakan suatu kegiatan dimana para ahli akan menilai produk dari peneliti berupa media pembelajaran permainan yang telah dikembangkan. Untuk penilaian peneliti menggunakan skala likert, dimana skor yang di dapat akan diinterpretasikan sesuai kriteria yang tersaji.

\section{Kelayakan Media Truth and Dare}

Berikut ini rekapitulasi hasil validasi kelayakan media pembelajaran permainan truth and dare

Tabel 3. Rekapitulasi validasi para ahli

\begin{tabular}{llll}
\hline No & Komponen & Prosentase & Kriteria \\
\hline 1. & Ahli Media & $96 \%$ & Sangat Layak \\
2. & Ahli Materi & $91 \%$ & Sangat Layak \\
\hline \multicolumn{2}{l}{ Rata-rata } & $93,5 \%$ & Sangat Layak \\
\hline \multicolumn{2}{l}{ Sumber : dikelola peneliti $(2020)$}
\end{tabular}

Dari segi kelayakan media terdapat dua poin penting yaitu kelayakan media tersebut dan isi materi yang ada di didalam media tersebut. Kelayakan media yang telah divalidasi oleh ahli media mendapatkan prosentase sebesar 96\% dengan kriteria "sangat layak" (Riduwan, 2016). Kelayakan penilaian materi dilakukan oleh satu orang guru mata pelajaran akuntansi dasar dan dosen pendidikan akuntansi untuk media pembelajaran truth and dare ini memperoleh prosentase rata-rata 91\% dengan kriteria "sangat layak" Hal ini dikarenakan bahwa materi yang ada di dalam media pembelajaran ini ini sangat sesuai indikator pembelajaran yang ada di SMK tersebut. Dalam media truth and dare ini juga melihat dari berbagai aspek mulai dari daya tarik peserta didik dalam menggunakan media tersebut, karena menurut hasil studi pendahuluan ke sekolah bahwa siswa di SMK Negeri 1 Sambeng lebih suka belajar sambil bermain. Menurut Sadiman (2014) sebagai media pembelajaran permainan memiliki kelebihan yaitu permainan adalah sesuatu yang menyenangkan untuk dilakukan karena menghibur dan menyenangkan. Berdasarkan analisis data yang dilakukan oleh Mita Rosyda Attaqiana, Saptorini, dan Ahmad Binadja (2016) menunjukkan bahwa hasil dari 41 dari 42 siswa mampu mencapai skor lebih dari 31 dengan kategori motivasi belajar tinggi hal ini menunjukkan bahwa salah satu indikator keberhasilan uji keefektifan media dalam penelitian tersebut telah tercapai.

\section{KESIMPULAN}

Berdasarkan uraian diatas dapat disimpulkan bahwa penelitian pengembangan media pembelajaran permainan truth and dare ini dikembangkan dengan tahap 4D menurut Thiagarajan, meliputi tahap pendefinisian (define), perancangan (design), pengembangan (develope) dan penyebaran (deseminate) tetapi dalam penelitian ini hanya sampai pada tahap pengembangan saja.

Berdasarkan hasil validasi kelayakan materi dan media pembelajaran permaian truth and dare ini menunjukkan penilaian dari para ahli validasi ahli media sebesar $96 \%$ dan dari dua ahli materi dari guru mata pelajaran di SMK yang diteliti dan salah satu dosen pendidikan akuntansi memperoleh prosentase rata-rata $91 \%$ sehingga kedua validasi tergolong kriteria "sangat layak". 


\section{DAFTAR PUSTAKA}

Al-Hibra, Bics. (2016). Pengembangan Media Pembelajaran Permainan Truth and Dare terhadap Hasil Belajar Ekonomi pada Materi Bank untuk Kelas X SMA. Skripsi. Surabaya: UNESA.

Arsyad, A. (2016). Media Pembelajaran. Jakarta: Rajawali Pers.

Ataupah, D. A. (2018). Peningkatan Hasil Belajar Biologi Materi Sistem Gerak Melalui Model Pembelajaran Kooperatif Tipe Make a Match Siswa Kelas-Xi Ipa Sma Negeri 8 Malang. JINoP (Jurnal Inovasi Pembelajaran), 4(1), 11-16.

Attaqiana, M. R., \& Binadja, A. (2017). Pengembangan Media Permainan Truth and Dare Bervisi Sets Guna Memotivasi Belajar Siswa. Jurnal Inovasi Pendidikan Kimia, 10(2), 1798-1806.

Kusuma, I., \& Irawati, S. (2013). Pengembangan Media Pembelajaran Melalui Permainan "Hunting Treasure" Pada Materi Himpunan Untuk Siswa Kelas Bilingual VII-A Di SMP Negeri 16 Malang. Jurnal Online UM, 1-7.

Liu, E. Z. F., \& Chen, P.-K. (2013). The Effect of Game-Based Learning on Students' Learning Performance in Science Learning - A Case of "Conveyance Go." Procedia - Social and Behavioral Sciences, 103, 1044-1051. International Educational Technology Conference.

Michael, O. N. \& Anugwo M. N. (2016). Card Games and Algebra Tic. Tacmatics on Achievement of Junios Secondary II Students in Algebratic Expressions. International Journal of Evaluation and Research in Education (IJERE).

Musfiqon. (2012). Pengembangan Media \& Sumber Pembelajaran. Jakarta: PT Prestasi Pustakarya.

Nugroho, Aris Prasetyo dkk. (2013). Pengembangan Media Pembelajaran Fisika Menggunakan Permainan Ular Tangga Ditinjau dari Motivasi Belajar Siswa kelas VIII Materi Gaya. Jurnal pendidikan Fisika Vol 1. Universitas Sebelas Maret.

Nurdin, Syafruddin \& Andriantoni. (2016). Kurikulum dan Pembelajaran. Jakarta: Raja Grafindo Persada.

Prafianti, Rinda Arseta. (2015). Pengembangan Permainan Truth and Dare Sebagai Media Pembelajaran Hidrokarbon untuk Siswa kelas XI SMA. Skripsi yang tidak dupublikasikan. Surabaya: UNESA.

Rastegarpour, H., \& Marashi, P. (2012). The effect of card games and computer games on learning of chemistry concepts. Procedia - Social and Behavioral Sciences, 31(2011), 597-601.

Riduwan. (2016). Skala Pengukuran Variabel-Variabel Penelitian. Bandung: Alfabeta.

Rohmah, Baety N. (2017). Pengembangan Media Pembelajaran Game Edukatif Fun Spreadsheet Quiz Berbasis Adobe Flash CS6 Pada Mata Pelajaran Spreadsheet Kelas X Akuntansi SMK Negeri 4 Klaten Tahun Pelajaran 2016/2017. Skripsi. Yogyakarta : UNY

Sadiman, A. S., Rahardjo, R., \& Haryono, A. (2014). Media pendidikan pengertian, pengembangan, dan pemanfaatannya. Jakarta: PT Raja Grafindo Persada.

Sanjaya, Wina. (2008). Perencanaan dan Desain Sistem Pembelajaran. Jakarta: Kencana.

Smaldino, S. E., Lowther, D. L., \& Russell, J. D. (2012). The ASSURE Model. In Instructional Technology and Media for Learning.

Sugiyono. (2016). Metode Penelitian Pendidikan (Pendekatan Kuantitatif, Kualitatif dan R\&D). Bandung: Alfabeta.

Susanto, Ahmad. (2013). Teori Belajar dan Pembelajaran SD. Jakarta: Kencana Prenada Media Group.

Tivani, I. (2016). Pengembangan LKS Biologi Berbasis Masalah untuk Meningkatkan Kemampuan Pemecahan Masalah dan Karakter Peduli Lingkungan Developing [roblemBased Biology Worksheet to Improve Problems Solving Skills and Environment Care Character, 2(1), 35-45. 
Oikos: Jurnal Kajian Pendidikan Ekonomi dan IImu Ekonomi, ISSN Online: 2549-2284

Volume IV Nomor 2, Juli 2020

Trianto. (2016). Mendesain Model Pembelajaran Inovatif, Progesif, dan Kontekstual: Konsep, Landasan, dan Implementasinya pada Kurikulum 2013 (Kurikulum Tematik Integratif/TKI). Pranadamedia Grup. 